\title{
The Effect of Giving Probiotics (Bio-Cas) on the Growth of Bali Cattle in Bunutan Village, Abang District, Karangasem Regency
}

\author{
Londra IM, Sudarma IW, Sutami P \\ Bali Assessment Institute for Agricultural Technology \\ Jl. By Pass Ngurah Rai, Denpasar 80222, Bali, Indonesia \\ londra_bptp@yahoo.co.id
}

\begin{abstract}
Since beef demand increases from year to year, it is necessary to meet the demand by an effort to increase the domestic cattle population and productivity. Supplementary feeding as well as probiotics treatment in the form of Bio-Cas can be done in order to improve the growth of cattle. The study was conducted in the village of Bunutan, Abang District, Karangasem Regency for six months from April to October 2015. The study used 18 male of Bali cattles with an average initial weight of $220 \mathrm{~kg} / \mathrm{head}$. Cattle were divided into three treatment groups, P.1: Cattle were fed based on usual management by the farmers P.2: As (P.1) plus the provision of Bio-Cas as much as 5 $\mathrm{cc} /$ head/day. P.3: As (P.2) plus rice bran $2 \mathrm{~kg} / \mathrm{head} /$ day. The results showed that cattle which were fed by an appropriate way for farmers (P1) increased in body weigh of $180 \mathrm{~g} / \mathrm{head} / \mathrm{day}$, giving BioCas as much as $5 \mathrm{cc} /$ head/day (P.2) increased body weight of $350 \mathrm{~g} /$ head/day mean while giving Bio-Cas as much as $5 \mathrm{cc} / \mathrm{head} /$ day plus bran $2 \mathrm{~kg} / \mathrm{head} / \mathrm{day}$ (P.3) weight gained $510 \mathrm{~g} / \mathrm{head} / \mathrm{day}$. Statistically, the three treatments showed significant difference $(\mathrm{P}<0.05)$. Giving rice bran as much as $2 \mathrm{~kg} / \mathrm{head} / \mathrm{day}$ plus Bio-Cas $5 \mathrm{cc} / \mathrm{head} / \mathrm{day}$, resulted in the highest $\mathrm{R} / \mathrm{C}$, so this treatment gave the highest benefit to the farmers.
\end{abstract}

Key Words: Cattle, Probiotics, Growth

\section{INTRODUCTION}

National beef demand in 2010 reached 402.9 thousand tonnes, in which the supply was only 282.9 thousand tonnes from local production. In order to meet the national demand for meat, the government imported 46.3 thousand tonnes of live cattle and 73.7 thousand tonnes of meat. Along with population growth and rising incomes, the demand for beef will continue to rise. Demand for beef in 2015 is predicted to increase to 467 thousand tonnes, or approximately 10\% from 2010 (BPS Kabupaten Karangasem 2015). To meet the demand of approximately 420.3 thousand tonnes obtained from local production and as many as 46.7 thousand tonnes in the meet of imports (Disnak Provinsi Bali 2014), as the increase in beef production, beef imports dropped dramatically. In 2009 the share of imports of beef are still $56 \%$ in 2013 to remain $13.69 \%$. This means that in five years beef imports has decreased by $75.56 \%$ (Sinartani 2014). Development of livestock sub-sector is essentially aimed at improving the population as well as livestock production and by-products, which in turn is expected to boost the income of livestock farmers, encourage diversification and improve the quality of nutrition and develop export markets, especially to achieve food sovereignity.

Therefore, one alternative for increasing food production is expanding to the dry land area, through the cultivation of crops and livestock, water supply, land conservation and rehabilitation of the land so that it will be productive land. Renewable materials management and sustainability is one of the principles of ecological farming, maintaining diversity, maintaining the strength of the community, to maximize long-term profits and increase the value of both human health and the environment (Reijntjes et al. 1992). 
Dusun Sega, Bunutan Village, Abang District, Karangasem Regency is a hilly area with an altitude of 400-500 meters above sea level, rainfall is relatively low, the total area of 3,057,330 hectares. The season in general in the Village of Bunutan strongly support the agricultural sector. On the rainy season, it is good for seasonal plants. Every year, various types of forage include farm waste (rice straw, corn waste, bean waste, cassava leaves), fruit plants (banana leaves, jack fruit leaves), gramineae group (elephant grass, cynodon grass) and also green forage (leucaena, gliricidia, gamelina) are available in the form of leaves and tubers and potential to support cattle farms.

To improve growth and efficiency of livestock feed, in addition to feeding both quantity and quality, the past few breeders have been using probiotics that contain useful microorganisms. Bio-Cas is a probiotic that help the digestive process of feed was developed by a researcher of Bali Assessment Institute for Agricultural Technology (BPTP Bali). Bio-Cas does not only contain some useful bacteria, but also contains natural substances (curcumin, allicin and scordinin) that can kill microbial pathogens such as $E$. coli, Salmonella sp. and Shigella sp. as well as increase appetite. Bio-Cas is in liquid form, with a distinctive aroma and slightly sweet taste. Probiotics can be administered directly into the mouth of cattle and can also be given through drinking water or mixed in the concentrate.

\section{MATERIAL AND METHODS}

The study was conducted in the village of Bunutan, Abang District, Karangasem regency for six months from April to October 2015. The study used 18 male of Bali cattle. All cattle were divided into three groups of feed treatment as follows: P.1: feed based on the appropriate farmers way; P.2: As (P1) plus the provision of Bio-Cas as much as 5 cc/head/day; and P.3: As (P2) plus bran $2 \mathrm{~kg} / \mathrm{head} / \mathrm{day}$.

The research used a completely randomized design with three treatments and six replicates. Data were analyzed by using Duncan multiple test with a level of confidence (significant level) $5 \%(\mathrm{P}<0.05 \%)$. The variables observed were average daily gain (ADG) and economic analysis of fattening using revenue cost ratio ( $\mathrm{R} / \mathrm{C}$ ratio).

The provision of Bio-Cas could be done with a syringe (without needle). Bio-Cas fluid aspirated into the syringe, and was inserted into the mouth, then the plunger was pushed to expel probiotics out. The dosage used for fattening cattle was $5 \mathrm{cc}$ or 1 tablespoon per cattle per day.

\section{RESULTS AND DISCUSSION}

The results showed that the cattle which were fed by an appropriate farmers way (P1) increased in body weight of $180 \mathrm{~g} / \mathrm{head} / \mathrm{day}$, giving Bio-Cas as much as $5 \mathrm{cc} / \mathrm{head} /$ day $(\mathrm{P} 2)$ increased body weight of $350 \mathrm{~g} / \mathrm{head} / \mathrm{day}$ meanwhile giving Bio-Cas as much as 5 $\mathrm{cc} /$ head/day plus bran $2 \mathrm{~kg} /$ head/day (P3), the cattle gained $510 \mathrm{~g} /$ head/day. Statistically, the three treatments showed a significant difference $(\mathrm{P}<0.05)$ (Table 1). Results of this research was lower than obtained by Widiyazid et al. (1999) in which the bran and the supplementation of bioplus to fattening cattle was able to increase the weight 620 $\mathrm{g} / \mathrm{head} / \mathrm{day}$. This was due to different type of probiotics that used to produce enzymes that help digestion of food.

The growth of cattle was less because of the availability of feed was very limited. Probiotics Bio-Cas was a product of feed additive containing microbial probiotics and some natural growth stimulants (organic) to accelerate the growth of ruminants. 
Giving Bio-Cas in cattle showed differences in appearance about two weeks after administration of Bio-Cas, appetite of livestock will increase and will appear more active. The skin and fur will look smoother and increased. Besides, the smell of manure was greatly reduced. After about four weeks, usually the response of the growth of cattle that given Bio-Cas would seem real. The addition of rice bran also contributed to the growth of cattle as the source of energy and protein. The same result has been reported by Parvati et al (1999) when they combined rice bran with bioplus as the probiotic and fed it to cattle.

Table 1. The growth of Bali cattle given probiotics (Bio-Cas) in Bunutan Village, Abang District, Karangasem Regency

\begin{tabular}{lccc}
\hline \hline Treatment & Initial body weight $(\mathrm{kg})$ & Final weight $(\mathrm{kg})$ & ADG $(\mathrm{g} / \mathrm{head} / \mathrm{day})$ \\
\hline P.1 & 220.50 & 251.50 & $180^{\mathrm{a}}$ \\
P.2 & 222.25 & 286.79 & $350^{\mathrm{b}}$ \\
P.3 & 219.25 & 307.00 & $510^{\mathrm{c}}$ \\
\hline
\end{tabular}

P.1: Farmer's way; P.2: Farmer's way + Bio-Cas; P.3: Farmer's way + Bio-Cas +2 kg bran

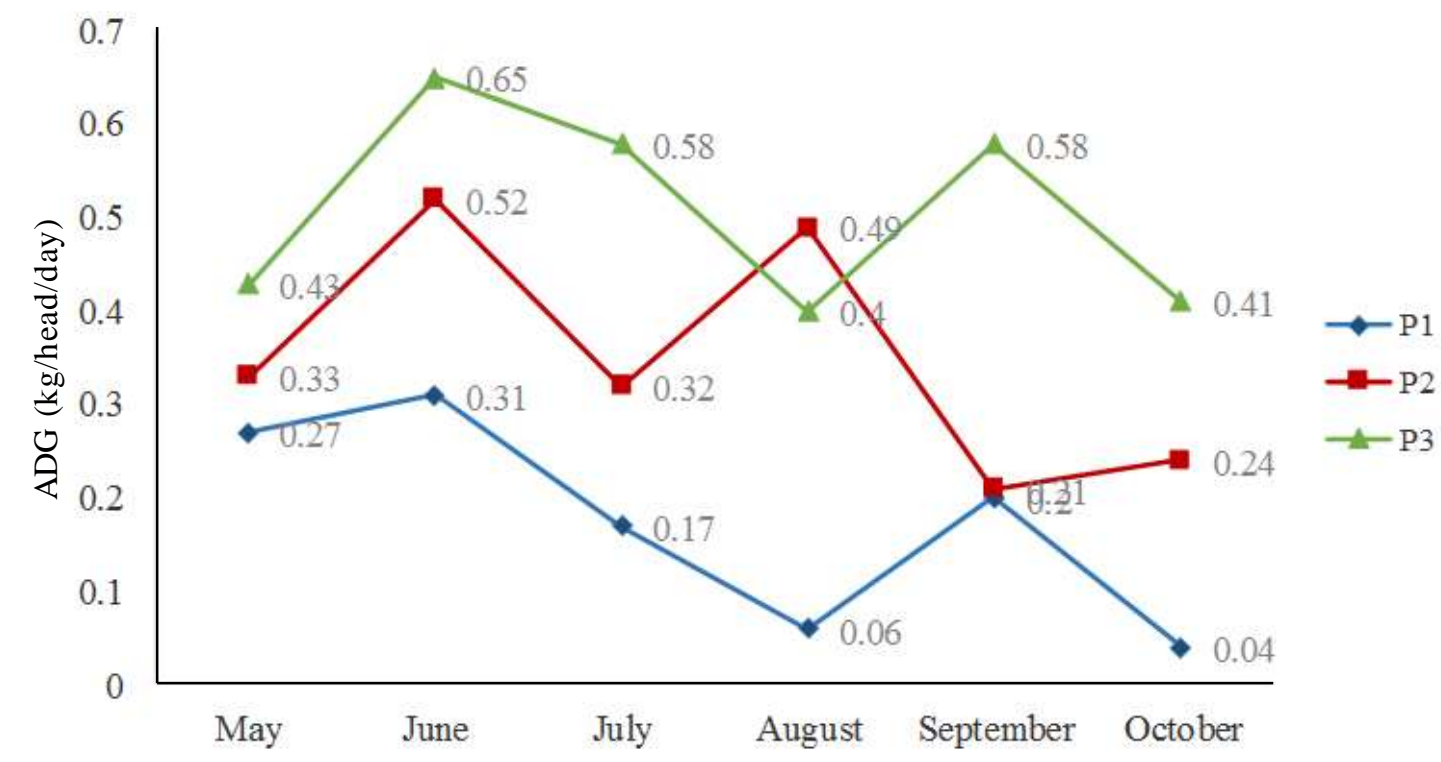

Figure 1. The average daily gain of cattle fed different diets in the Village of Bunutan, Abang District, Karangasem regency

In the formulation of Bio-Cas scaling up technique was easy, guaranteed free of pathogens and still contains substances that could respond to the real growth of livestock. Rumen fluid contents contained probiotic bacteria (Ruminococcus sp). The pathogenic microbes under certain condition could inhibit the population of probiotic bacteria and at a certain population level could endanger the health of livestock.

An economic analysis of cattle using Bio-Cas plus $2 \mathrm{~kg} / \mathrm{head} / \mathrm{day}$ rice bran (P.3) shows that overall costs such as feed, medicines, and labor amounted to Rp. 13.02 million. With the input obtained from the sale of cattle Rp. 16.75 million and sale of cow dung Rp. 350,000 , brought the total revenue for farmers amounted to $\mathrm{Rp}$. 17.1 million. R/C was 1.31, which means the activity to fattening cattle is feasible to be developed as it is profitable, as presented in Table 2 . 
Table 2. Economic analysis of cattle fed different diets over six months in the Village of Bunutan, Abang District, Karangasem regency

\begin{tabular}{lccr}
\hline \hline \multirow{2}{*}{ Expenditure (Rupiah) } & \multicolumn{3}{c}{ Treatment } \\
\cline { 2 - 4 } & \multicolumn{1}{c}{$\mathrm{P} .1$} & $\mathrm{P} .2$ & \multicolumn{1}{c}{$\mathrm{P} .3$} \\
\hline Cattle purchase & $8,500,000$ & $8,500,000$ & $8,500,000$ \\
Bio-Cas & - & 30,000 & 30,000 \\
Concentrate & & & \\
P.3: 360 kg rice bran (@ Rp. 3,000) & - & - & $1,080,000$ \\
Medicine & 50,000 & 50,000 & 50,000 \\
Decreased of stall & 60,000 & 60,000 & 60,000 \\
Forage (5,400 kg $\times$ Rp. 500) & $2,700,000$ & $2,700,000$ & $2,700,000$ \\
Labor & 600,000 & 600,000 & 600,000 \\
\hline Total (Rupiah) & $11,910,000$ & $11,940,000$ & $13,020,000$ \\
\hline Revenue livestock sales results (Rupiah) & & & \\
Livestock & $12,250,000$ & $14,250,000$ & $16,750,000$ \\
Fertilizer & 350,000 & 350,000 & 350,000 \\
Total revenue & $12,600,000$ & $14,600,000$ & $17,100,000$ \\
Profit & 690,000 & $2,660,000$ & $4,080,000$ \\
R/C ratio & 1.06 & 1.22 & 1.31 \\
\hline
\end{tabular}

\section{CONCLUSION}

Provision of Bio-Cas as much as $5 \mathrm{cc} / \mathrm{head} /$ day or rice bran $2 \mathrm{~kg} / \mathrm{head} / \mathrm{day}$ plus BioCas $5 \mathrm{cc} / \mathrm{head} /$ day significantly improve the body weight of male Bali cattle. Provision of rice bran as much as $2 \mathrm{~kg} / \mathrm{head} / \mathrm{day}$ plus Bio-Cas $5 \mathrm{cc} / \mathrm{head} /$ day gave the highest $\mathrm{R} / \mathrm{C}$ ratio, so that it gave the highest benefit to the farmers.

\section{REFERENCES}

BPS Kabupaten Karangasem. 2015. Monografi Desa Bunutan, Kecamatan Abang, Kabupaten Karangasem. Karangasem (Indoenesia): BPS Kabupaten Karangasem.

Disnak Provinsi Bali. 2014. Laporan Cacah Jiwa Ternak Propinsi Bali Tahun 2014. Denpasar (Indonesia): Dinas Peternakan Provinsi Bali.

Parwati IA, Suyasa N, Guntoro S, Yasa IMR. 1999. Pengaruh pemberian probiotik dan laser punktur dalam meningkatkan berat badan sapi Bali. Dalam: Haryanto B, Murdiati TB, Djajanegara A, Supar, Sutama IK, Setiadi B, Darminto, Beriajaya, Abubakar, penyunting. Prosiding Seminar Nasional Peternakan dan Veteriner. Bogor, 18-19 Oktober 1999. Bogor (Indonesia): Puslitbangnak. hlm. 136-146.

Reijntjes C, Haverkort B, Bayer AW. 1992. Farming for the future, an introduction to lowexternal-input and sustainable agriculture. London (UK): The Macmillan Press Ltd.

Suyasa N, Guntoro S, Widiazid S, Suprapto, Parwati IA. 1997. Pemanfaatan probiotik dalam pengembangan sapi potong berwawasan agribisnis di Bali, 1998. Denpasar (Indonesia): Instalasi Penelitian dan Pengkajian Teknologi Pertanian Denpasar.

Widiyazid IKS, Parwati IA, Suyasa N, Guntoro S, Londra IM, Triagastia IK, Adnyana PAAG, Widianta GM. 1999. Laporan Akhir Pengkajian Sistem Usaha Pertanian Sapi Potong Berbasis Ekoregiona Lahan Kering. Denpasar (Indonesia): Instalasi Penelitian dan Pengkajian Teknologi Pertanian Denpasar. 